\title{
Capacity of Local Government Tanah Karo Regency in Responding to Mount Sinabung Eruption in Indonesia
}

\author{
Tunggul Sihombing ${ }^{1}$, Henri Sitorus ${ }^{2}$, Yusuf L. Henuk ${ }^{3}$ \\ ${ }^{1}$ Department of Public Administration, Faculty of Social and and Policical Science, University of Sumatera Utara, \\ Medan, Indonesia \\ ${ }^{2}$ Department of Sociology, Faculty of Social and Political Science, University of Sumatera Utara, Medan, Indonesia \\ ${ }^{3}$ Director Postgraduate Studies, State Institute for Christian Studies (IAKN), Tarutung, North Tapanuli, North \\ Sumatera, Indonesia
}

\begin{abstract}
Local governments have an important role in minimizing disaster risk. This is related to development goals in the region. Therefore, local governments must have the capacity to guide the community in order to minimize disaster risk. This aspect is contained in the context of this paper, namely knowing the capacity of the Tanah Karo Regency Government in minimizing the risk of the eruption of Mount Sinabung. In minimizing disaster risk, the Tanah Karo Regency Government has established the Regional Disaster Management Agency (BPBD) since 2014, although it is quite late compared to the Mount Sinabung eruption that has occurred since 2010. accurately and efficiently. In addition, the Tanah Karo Regency BPBD has the function of coordinating disaster management in an integrated manner. These vital duties and functions must be balanced with the capacity of an established BPBD institution. However, the process towards the establishment of the institutional capacity is not an instant process. In the early days of the existence of BPBD Tanah Karo Regency faced challenges, especially the role of the National Disaster Management Agency (BNPB) which had not yet declared the Mount Sinabung eruption disaster as a national disaster. What can be concluded from this phenomenon is that the BPBD of Tanah Karo Regency must get accelerated institutional capacity building. So that the duties and authorities of the Tanah Karo Regency BPBD can carry out their functions and authorities effectively and efficiently, especially in minimizing the risk of the Mount Sinabung eruption disaster.
\end{abstract}

Keywords: Disaster response, capacity, local government, organizational development

\section{INTRODUCTION}

It is not new if Indonesia is known as one of the countries most prone to natural disasters. These disasters often cause casualties, eliminate people's jobs, and massive damage to property, infrastructure, and the environment. The tsunami disaster that hit Aceh Province and several regions in Indonesia on December 26, 2004 prompted the Indonesian government to reform and strengthen the disaster management system. Since the incident, the government and society have realized the importance of a disaster management system by prioritizing disaster risk reduction.

The reform efforts undertaken by the Government of Indonesia since 2004 have made some progress, such as the adoption of the United Nations Hyogo Framework for DRR Action (HFA-DRRR). The framework is a 10-year plan designed to minimize the risk of natural disasters. The government has also passed Law Number 24 of 2007 concerning Disaster Management to strengthen the paradigm of disaster risk reduction. In addition, the
Government of Indonesia has established a national disaster management agency called the National Disaster Management Agency, and the concept of disaster risk management has been established as a national development priority. This achievement is a form of Indonesia's paradigm shift in disaster management, namely the technical approach to responding to disasters to reducing disaster risk.

The Indonesian government is committed to tackling disaster risk by minimizing disaster risk through BNPB institutionalization, laws and regulations, and budgeting. In addition, this commitment can be seen through the implementation of a disaster management system through a national development planning and budgeting system. According to BNPB (2013), the 
integration has proven to increase budget absorption in reducing disaster risk nationally, where in the last five years (2008-2013), at least programs related to disaster management are generic in nature reaching 82 percent and for certain disasters by 18 percent. The purpose of this paper is to evaluate the capacity of the Tanah Karo Regency Government in dealing with the Mount Sinabung eruption disaster.

\section{MOUNT SINABUNG ERUPTION IN TANAH KARO DISTRICT}

Mount Sinabung is a type B strato volcano. However, the history of this volcanic eruption is still unknown. The Type of B means that ie the volcano is not did not have meaningful activity in more than hundred years and therefore it was not included as priority for monitoring. It was known form the Center of Volcanology and Geologhical Disaster Mitigation (PVMBG) that the last eruption took place in 1600. Mount Sinabung erupted phreatic explosion on August 27, 2010. From 2010 to 2013, Mount Sinabung experienced an increase in volcanic activity, such as rain of ash, material, and water vapor emissions. Besides, some of the volcanic activities that occur often cause short seismic waves and tremors in the hours before the eruption, although the initial and final stages of the eruption period cannot be known for sure. Mount Sinabung erupted again on September 15, 2013 and increased the risk of disaster, especially for the surrounding community. Since then, Mount Sinabung has often erupted until now, so that residents around the mountain are not safe. On September 18, 2013, the government evacuated at least 12,950 people around the affected area to a safer area. The eruption had a direct impact on three villages within a $5 \mathrm{~km}$ radius. ${ }^{1}$ In addition to forcing the community to evacuate, the disaster resulted in the livelihoods of the local community, most of whom were farmers, experiencing heavy losses.

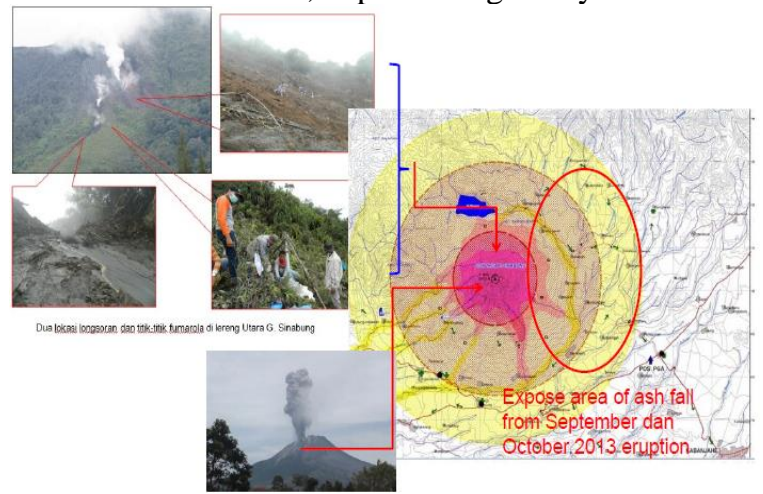

Figure 1. The impact of the eruption of Mount Sinabung and the affected area

Population in the red zones area have been relocated, including those placed in the Siosar area as could see in Figure 2.

1 Pusat Vulkanologi dan Mitigasi Bencana Geologi, Kementerian Energi dan Sumberdaya Mineral (2013).

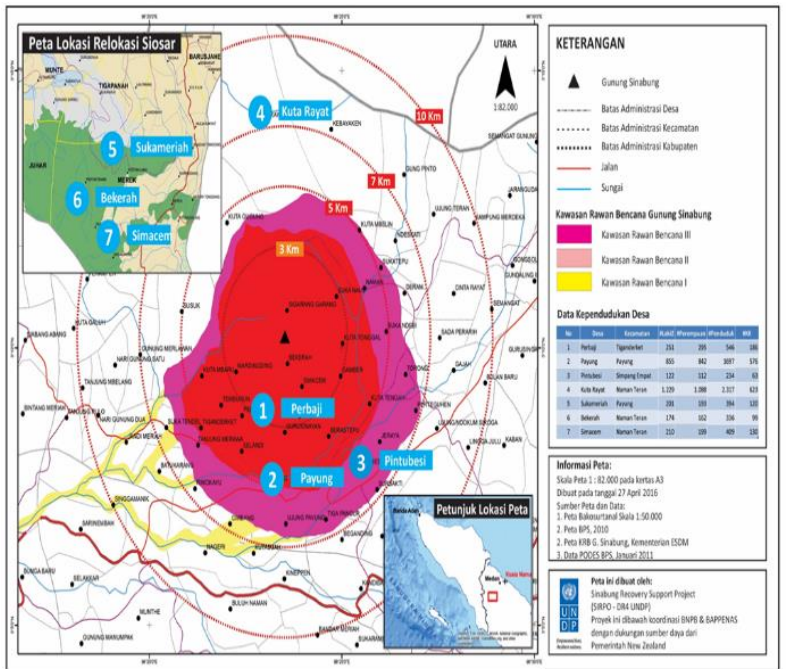

Figure 2. The area affected by the eruption of Mount Sinabung

\section{CAPACITY IN DISASTER RESPONSE}

In the Hyugo Framework for Action (HFA) launched at the World Conference on Disaster Reduction (WCDR) which was ratified by Indonesia along with 167 WCDR member countries, it emphasized that "the intrinsic relationship is between disaster reduction, sustainable development and poverty alleviation". WCDR member countries recognize the vital role of involving all stakeholders, including central government, local governments, including international institutions and financial institutions, communities, non-governmental organizations, academia, the private sector, and volunteers. The declaration also states that the state is the party most responsible for protecting citizens and their property from disasters. Another thing emphasized in the declaration also concerns the formulation of national policies that are in accordance with capacity building at the community level regarding disaster risk.

Significant progress has been achieved in the disaster management in Indonesia. The Indonesian government ratified the Hyogo Framework for Action on Disaster Risk Reduction in 2005 through the establishment of a national disaster management action plan implemented by the National Disaster Management Agency. This is also reflected in Law Number 24 of 2007 concerning Disaster Management which contains legal rules regarding the disaster management coordination system. The declaration is an important foundation in disaster management. According to the World Bank (2004:49), disasters cause serious social disturbances in the community, especially in terms of massive loss of life, material, economic, and environmental victims and exceeds the ability of the affected parties if they use their own abilities. Meanwhile, according to Warfield (2004), disaster management aims to minimize or avoid potential 
hazards, losses, and ensure quick and effective assistance.

In the context of disaster management in Indonesia, BNPB and BPBD act as institutions that plan, coordinate post-disaster recovery, carry out recovery organized by ministries and regional work units that have the task of handling certain activities. In carrying out disaster area recovery, BNPB must be able to clearly identify disaster impacts, identify needs for post-disaster recovery, and design recovery action plans with post-disaster recovery programs and budgets. (GFDRR, UNDP, and World Bank, 2014).

Meanwhile at the regional level, the regional government establishes the Regional Disaster Management Agency (BPBD) which has the same duties and authorities as BNPB, as mandated in Article 20 of Law No. 24 of 2007, namely carrying out disaster management tasks, both at the provincial and district/city levels.

\section{LOCAL GOVERNMENT CAPACITY IN DISASTER MANAGEMENT}

According to the United Nations Office for Disaster Risk Reduction (2009), disaster management is a systematic process through administrative decisions, organization, operational capabilities, and capacity in policy implementation, approaches to the community in minimizing the impact of natural, environmental and technological disasters. The United Nations Office for Disaster Risk Reduction (2004), also explains that minimizing disaster risk means a conceptual framework by considering the possibility of vulnerability and disaster risk for the community, so that the community is spared and prepared to face the adverse effects of disasters, including in the process of sustainable development.

In carrying out the function of disaster management, local governments must have adequate capacity. The required capacity, such as: a. Reducing disaster risk and integrating it into regional development programs; b. Protect the community from the impact of disasters; c. Ensure the fulfillment of the rights of disaster-affected communities in refugees fairly and in accordance with minimum service standards; d. Restoring disasteraffected areas; e. Allocate budget for disaster management; f. Provide disaster management funds in the annual budget, and g. Securing authentic archives/documents from threats and impacts of disasters.

According to Law No. 24 stipulates that the capacity of local government shall include the following: a. Establish disaster management policies in regional development policies, b. Planning development by taking into account elements of disaster management policies; c. Implement disaster management policies by cooperating with other provinces, regencies/cities; d. Regulate the use of technology that has a potential disaster threat in the area; e. formulating policies that prevent the control or loss of natural resources beyond the capacity of recovery; and $\mathrm{f}$.
Examine financial sources, including the collection and distribution of aid at the provincial, district/city levels. In the context of the Mount Sinabung eruption disaster, the Tanah Karo Regency Government has established a BPBD on January 22, 2014 through the Tanah Karo Regency Regulation Number 1 of 2014. In this regulation, the Tanah Karo Regency BPBD is responsible for disaster management as mandated in Regional Regulation Number 19 of 2008.

\section{LOCAL GOVERNMENT CAPACITY IN DISASTER MITIGATION, EMERGENCY RESPONSE AND REHABILITATION FOR MT. SINABUNG ERUPTION}

Though the main government unit in disaster management is BPBD, the research investigate the role of Bappeda (Local Development Planning Agency), Dinas Sosial (Social Affairs Office), Dinas Pendidikan (Office of Education), Dinas Kesehatan (Office of Health Services), Dinas Pertanian (Agriculture Office). The capacity assessed in the research are based on Hyogo Framework, as lited below.

\begin{tabular}{|c|c|}
\hline Capacity & Description \\
\hline $\begin{array}{l}\text { Establish an organization } \\
\text { that coordinates related } \\
\text { parties with clear roles } \\
\text { [HFA PRIORITY 1] }\end{array}$ & $\begin{array}{l}\text { The BPBD is mandated } \\
\text { for coordination, } \\
\text { however since the unit is } \\
\text { parallel with other } \\
\text { governmental units, } \\
\text { often the coordination } \\
\text { role of BPBD is weak. } \\
\text { Though the ex-officio } \\
\text { head is the District } \\
\text { Secretary, but } \\
\text { operationally the role of } \\
\text { Head is not well- } \\
\text { performed }\end{array}$ \\
\hline $\begin{array}{l}\text { Establish budgets and } \\
\text { incentives for disaster } \\
\text { victims who lost } \\
\text { property, low-income } \\
\text { families, and the private } \\
\text { sector investing in } \\
\text { disaster risk reduction } \\
\text { [HFA PRIORITIES } 1 \\
\text { AND 4] }\end{array}$ & $\begin{array}{l}\text { The budget capacity of } \\
\text { the local government is } \\
\text { lower than the material } \\
\text { and monetary effect. }\end{array}$ \\
\hline $\begin{array}{l}\text { Updating data on } \\
\text { disaster hazard and } \\
\text { vulnerability while } \\
\text { preparing a disaster risk } \\
\text { assessment [HFA } \\
\text { PRIORITIES } 2 \text { and } 3 \\
\text { AND 4] }\end{array}$ & $\begin{array}{l}\text { As a new agency, BPBD } \\
\text { of Tanah Karo has } \\
\text { limited resources and } \\
\text { capacity (both } \\
\text { organizational and } \\
\text { personnel capacity). } \\
\text { Therefore, the role to } \\
\text { update data and } \\
\text { vulnerabilities is not } \\
\text { systematic. }\end{array}$ \\
\hline
\end{tabular}




\begin{tabular}{|c|c|}
\hline $\begin{array}{l}\text { Invest in infrastructure } \\
\text { that maintains and } \\
\text { reduces disaster risk } \\
\text { [HFA PRIORITIES 4] }\end{array}$ & $\begin{array}{l}\text { Central government } \\
\text { through Public Works } \\
\text { Ministry takes initiatives } \\
\text { for infrastructure } \\
\text { development. However, } \\
\text { the role of local } \\
\text { government is } \\
\text { supporting the } \\
\text { infrastructure } \\
\text { development. }\end{array}$ \\
\hline $\begin{array}{l}\text { Review and if necessary } \\
\text { improve the security of } \\
\text { all public education and } \\
\text { health facilities in } \\
\text { disaster-prone areas } \\
\text { [HFA PRIORITIES 2, } 4 \\
\text { AND 5] }\end{array}$ & $\begin{array}{l}\text { The priority areas are in } \\
\text { the red zones only, } \\
\text { however, the impact } \\
\text { covers almost all Tanah } \\
\text { Karo District. }\end{array}$ \\
\hline $\begin{array}{l}\text { Provide education and } \\
\text { training programs on } \\
\text { minimizing disaster risk } \\
\text { in educational facilities } \\
\text { and to the community } \\
\text { [HFA PRIORITIES } 1,3 \\
\text { AND 5] }\end{array}$ & $\begin{array}{l}\text { The disaster risk } \\
\text { reduction is not } \\
\text { mainstreamed in } \\
\text { education and } \\
\text { communities. Irregular } \\
\text { training and evacuation } \\
\text { simulation were } \\
\text { organized. }\end{array}$ \\
\hline $\begin{array}{l}\text { Protecting natural tools } \\
\text { that can reduce disaster } \\
\text { risk and adapt to climate } \\
\text { change [HFA } \\
\text { PRIORITY 4] }\end{array}$ & $\begin{array}{l}\text { There is limited research } \\
\text { on ecosystem impact of } \\
\text { the Mt Sinabung } \\
\text { eruption }\end{array}$ \\
\hline $\begin{array}{l}\text { Install early warning } \\
\text { system and emergency } \\
\text { management capacity } \\
\text { [HFA PRIORITIES } 2 \\
\text { AND 5] }\end{array}$ & $\begin{array}{l}\text { With the help of UN } \\
\text { Joint Programme, the } \\
\text { early warning has been } \\
\text { introduced, but due to } \\
\text { lack of infrastructure } \\
\text { (computer hardware) the } \\
\text { system is no longer in } \\
\text { operation }\end{array}$ \\
\hline $\begin{array}{l}\text { Ensuring the needs and } \\
\text { participation of affected } \\
\text { people to be } \\
\text { reconstruction center } \\
\text { [HFA PRIORITIES } 4 \\
\text { AND 5] }\end{array}$ & $\begin{array}{l}\text { The participation of } \\
\text { communities in the } \\
\text { decision making is very } \\
\text { low. }\end{array}$ \\
\hline
\end{tabular}

\subsection{Capacity in Relocation}

The affected population have not yet equally relocated particularly those in red zones. There have been 370 households $(\mathrm{HH})$ from 3 villages within radius of $3 \mathrm{~km}$ (Bekerah, Simacem, and Sukemeriah) have been relocated in Siosar. People have settled in their permanent houses (huntap) equipped with public fasilities. However, others households are still in the evacuation center and partial have been asked to independent relocation.

\subsection{Capacity in Education Services}

Education services are prioritized in that the school aged children continue their education. However, the services provided such as transportation is limited. This was indicated by the accident of the un-decent school bus provided by the local government in September 2017, causing death of 1 student and injury of 35 students.

\subsection{Capacity in Livelihood Recovery}

The livelihood impact of Mount Sinabung eruption is widespread across all Tanah Karo District, including agriculture productivity loss in neighboring districts. However, the interventions for agriculture recovery is limited. The interventions of livelihood recovery was intensive in the Siosar relocation areas, which were also supported by international donors (such as FAO, ILO and UNDP). In Siosar, adaptive livelihoods promoted include organic horticulture, livestock raising, sewing and automotive workshop/services. Adaptive livelihood is also promoted through capacity building in coffee cultivation, production enhancement of coffee, and postharvest processing. The commodity of coffee become strategic since this cash crop is resilient to volcano ash. Moreover, coffee has been practiced by farmers community, with limited technology. However, livelihoods recovery support in other locations are limited.

\section{CONCLUSIONS}

The capacity of local government of Tanah Karo Regency in responding to Mount Sinabung eruption has not yet been implemented at the optimum level. This was affected by the fact that the Mount Sinabung eruption has not been categorized as national disaster. In addition, the RENAKSI (action plan) has not yet comprehensively prepared and adopted. The BPBD is mandated for coordination, however since the unit is parallel with other governmental units, often the coordination role of BPBD is weak. Though the ex-officio head is the District Secretary, but operationally the role of Head is not wellperformed. The budget capacity of the local government Tanah Karo Regency is lower than the material and monetary effect. As a new agency, BPBD of Tanah Karo has limited resources and capacity (both organizational and personnel capacity). Therefore, the role to update data and vulnerabilities is not systematic. In addition, The disaster risk reduction is not mainstreamed in education and communities. Irregular training and evacuation simulation were organized. Therefore, the research argues that there is a strong need for enabling capacity of local government in disaster management in Tanah Karo District. 


\section{REFERENCES}

[1] BNPB (2013) NATIONAL ASSESSMENT REPORT on Disaster Risk Reduction 2013. BNPB. https://www.bnpb.go.id/uploads/migration/pubs/57 3.pdf. Accessed on 21 September 2021.

[2] BNPB (2010). Rencana Nasional Penanggulangan Bencana 2010-2014. In: BNPD (ed.). BNPB. 2012. Badan Nasional Penanggulangan Bencana [Online]. Available: http://www.bnpb.go.id/. Accessed on 21 September 2021.

[3] Brooks, N., Klau, K., Orr, J. \& Stanford, C. (2010). Corruption in Natural Disaster Aid: The 2004 Indonesian Tsunami. Deakin Papers on International Business Economics, 3, 34.

[4] Cannon, T. (2008). Vulnerability, "innocent" disasters and the imperative of cultural understanding. Disaster Prevention \& Management, 17: 350-357.

[5] GFDRR, UNDP, WORLD BANK (2014). Institutionalizing Post-Disaster Recovery: Learning from Mentawai Tsunami and Merapi Eruption September 2014 Recovery Framework Case Study. https://www.gfdrr.org/sites/gfdrr/files/Indonesia\% 20Post-

Disaster\%20Recovery\%20Institutionalization.pdf. Accessed on 21 September 2021.

[6] Kusumasari, Bevaola. (2014). Manajemen Bencana dan Kapabilitas Pemerintah Lokal. Yogyakarta: Gava Media.

[7] The World Bank. (2006). Hazards of Nature, Risks to Development:An IEG Evaluation of World Bank Assistance for Natural Disasters. Washington, DC

[8] UNISDR. (2007). Hyogo Framework for Action 2005-2015: Building the Resilience of Nations and Communities to Disasters.

[9] UNISDR. (2009). Global Assessment Report on Disaster Risk Reduction - Risk and poverty in a changing climate. Geneva: United Nations.

[10] United Nations International Strategy for Disaster Reduction (UN/ISDR). (2009). UN/ISDR terminology on disaster risk reduction (2009). Retrieved from http://www.unisdr.org/eng/library/lib-terminologyeng.htm. Accessed on 21 September 2021.

[11] United Nations International Strategy for Disaster Reduction (UN/ISDR). (2004). Terminology: Basic terms of disaster risk reduction. Retrieved from www.unisdr.org/eng/library/lib-terminologyeng\%20home.htm. Accessed on 21 September 2021. 